\title{
English Language Anxiety and the Delivery in Oral Communications
}

\author{
JERRANICA C. GUMOP-AS \\ http://orcid.org/0000-0003-3255-7308 \\ jeanica532@gmail.com \\ VIDA MAY T. DE JUAN \\ http://orcid.org/0000-0001-6369-567X \\ vidadejuan@gmail.com
}

\begin{abstract}
As a developing country, the Philippines encourages its human resources to learn the English language to become globally competitive. As much as it is not technically considered as a second or foreign language, many Filipinos, especially in the rural areas still find English as a new and difficult language. This research is anchored on the theories of Krashen (1987) on Second Language Acquisition and Horwitz et al. (1986) on Foreign Language Anxiety. The study aimed to assess the English Language Anxiety and the Delivery in Oral Communications in relation to the Academic Performance among Grade 8 students at Union National High School in Ubay, Bohol. Using a purposive complete enumeration, the study employed a questionnaire patterned after the "Foreign Language Classroom Anxiety Scale (FLCAS)" and a rubric patterned from the Rubric for the Assessment of Oral Communication for Delivery" used by Valencia Community College in Orlando, Florida. Using documentary analysis, the raw scores from a periodical test administered during the course of the study were utilized. Data were treated to Chisquare and Pearson $r$ moment of correlation to test relationships among variables. Results show that there was no significant degree of correlation between the English Language Anxiety and the students' Oral Communication Delivery; however, there was a significant degree of corre-
\end{abstract}


lation between the Oral Communication Delivery and Academic Performance.

Keywords: Second Language Acquisition, Foreign Language Anxiety, Quantitative, Chi-Square, Pearson R moment of correlation, Ubay, Bohol, Philippines

\section{INTRODUCTION}

Language is a powerful bridge that connects people to the world, towards others and even towards the self. In this time and age, the English language has been a tool of choice for communication among many countries. A common language supports the idea of harmony among nations. In the ASEAN, the English language is considered the working language and the sole official language of the organization (Kirkpatrick, 2008). As a developing country in the ASEAN, the Philippines encouraged its human resources to learn the English language to become globally competitive in terms of job competence and effectiveness in the different industries as well as in becoming ambassadors of friendship and goodwill among nations.

Anxiety is considered to be a negative affective variable that makes learners feel nervous and frightened which greatly affect their oral communication skills. It has been described as being a subjecting feeling of apprehension, nervousness, tension and worry. Just as how some people consider anxiety as a factor in being successful in Science or in other subjects, many people also find presenting oral skills particularly in a classroom setting, stressful. This finding is evident with the studies of Horwitz, Horwitz \& Cope (1986); Maclntyre \& Gardner (1991); and Young (1991), particularly the western countries, where the studies conducted showed the relationship between the effect of anxiety and the success of learning foreign languages. The studies of Horwitz et al. (1986) and Maclntyre \& Gardner (1991) concluded that anxiety and success in learning the foreign language are negatively correlated.

In the Philippines, the educational system included the English language as a medium of instruction. However, learning a second language is not that easy specifically within a language class wherein students are encouraged to read, write, and speak a new language. Language learners experience anxiety which results in a mental block, stuttering, unconscious use of verbal and non-verbal fillers, sweating, and fast beating of the heart. 
Perhaps, language learning anxiety is the affective factor that obstructs the learning process and student academic achievement in the English class.

The researchers would like to understand better the complex process and the success of learning a second language. It is the prime objective of the researcher to find out the relationship of language anxiety and oral communication delivery in relation to student's academic achievement in the English classes of Grade 8 High School students in Union National High School located at Union, Ubay, Bohol where the researcher is presently assigned.

Second Language Acquisition Theory is proposed by Krashen (1987), he said that there are five main hypotheses which made up this theory. First is Acquisition-Learning Hypothesis, which states that adults have two ways of developing competence in the second language: 1) acquisition or the subconscious learning and 2) learning or the conscious learning. The acquisition is described as similar to the process that a child undergoes upon acquiring his first language. This requires a process of undergoing natural communication or conversation to acquire knowledge on the language. The learning is described as a product from formal schooling instruction that requires knowledge on the language such as learning the rules of grammar. Here, Krashen believes that acquisition or learning the language unconsciously is much more important than learning the language in formal education.

Second is Natural Order Hypothesis, which states that acquiring grammatical structures follows a predictable order. It further explains that the order depends on the child's background, age and exposure to the environment. Krashen further enforced that grammatical sequence should be rejected if the goal is language acquisition.

Third is Monitor Hypothesis, which focuses primarily on learning. While the child acquires language, frequent monitor through formal education should be reinforced for successful language acquisition.

Fourth is Input Hypothesis, which dictates that speaking fluency happens over time. Acquisition of language will happen when we are exposed to the language beyond our level. This hypothesis suggests that when a learner is learning in his early stages the beginnings of letters and sounds, the acquisition is far at par.

The fifth is Affective Filter Hypothesis, which explains that low affective filter contributes to good learning. This means that the affective variables such as confidence, motivation, and anxiety affect the acquisition of the 
second language. This theory dictates that learners who have a high level of confidence, motivation and self- esteem and low level of anxiety can do better in the acquisition of the second language.

According to Horwitz et al. (1986), Foreign Language Anxiety (FLA) Theory is a complex construct of beliefs, behavior and self-perception related to the classroom learning of language arising from the uniqueness of classroom language learning arising from the uniqueness of language learning process. They have drawn three related performance anxieties namely, communication apprehension, test anxiety and fear of negative evaluation. To measure such, they formulated FLCAS-33-item test which measures the student's belief, perception, and attitudes towards language anxiety. The results showed that significant level of foreign language anxiety is experienced by many students in response to 19 of 33 items. Thus, anxious students are evident in a foreign language class.

Vygotsky (1978) defined Zone of Proximal Development (ZPD) as "the distance between the actual developmental level as determined by independent problem solving and the level of potential development as determined through problem-solving done with adult guidance, or in tandem with more capable peers." This means that the child's actual development is measured by activities he can do independently. Zone of proximal development measures the activities where the child is not yet fully matured with that needs collaboration among peers and adults. Vygotsky in his theory views interaction with peers as an effective medium to develop skills and strategies. He further suggests that cooperative learning activities between a less competent child and skillful peers are a must within a zone of proximal development. Through ZPD, the child's confidence will be boosted to do tasks such as learning the foreign language. This theory simply implies that for a child to develop his skills and his potentials, a good way to maximize and to effectively learn worthwhile would be collaborative work were a skillful peer would be helpful in learning skills were one is not fully a master of.

Language anxiety is a complex psychological construct requiring investigation from a variety of perspectives and approaches. For McCintyre and Gardner (1991), anxious students are those individuals who feel that using the second language is a frightening situation wherein students withdraw from participating and feel intense social pressure in committing mistakes and are less active in participating with linguistic drills. Foreign language anxiety can be categorized into other types of anxiety and has a negative effect on the process of second language acquisition. 
Moreover, Burden (2004), believes that anxiety often manifest the feeling of incompetence. The fear of judgment and scrutiny can be minimized with the use of the teacher as facilitator of pair work, group and collaborative activities that will foster support and reassurance. Eliminating standards in a competitive environment could lessen anxiety and boost students' selfesteem. This is likewise supported by Li and Pan (2009) who believe that motivation is a factor in the success of second language acquisition. The students who have higher motivation obtain greater success in language learning than those who have low motivation who also often fail in exam. A student who lacks motivation most likely fails no matter who is the teacher and what is in the curricula, on the other hand, those who are highly motivated are most likely to succeed in whatever circumstance.

The student perspective has been a well-documented aspect (Horwitz 1986 \& McCintyre 1991) and has already contributed to the needed information about anxiety towards learning the language and performance. In line with this, it is but important to tap teachers nor specialists to completely understand this complex psychological phenomenon.

The student perspective has been a well-documented aspect in Horwitz et al. (1986) and McCintyre (1991) and has already contributed in the needed information about anxiety towards learning the language and performance. In line with this, it is but important to tap teachers nor specialists to completely understand this complex psychological phenomenon.

In the study of Young (1992) she interviewed four language specialists who were scholars as well as teachers but not necessarily experts on language anxiety. These specialists were Stephen Krashen, Alici Omaggio Hadley, Tracy Terrel and Jennybelle Rardin who were interviewed about their perspectives in English language anxiety.

Moreover, Young further questioned these specialists about what could be effective anxiety management strategies. Krashen said that if the Input hypothesis where the topics are comprehensible and interesting and the students are not pushed to speak and perform beyond the standards, then anxiety can be reduced. Omagglo Hadley, on the other hand, said that no to putting someone on the spot. He also believes that group activities engaging the macro-skills could lessen anxiety. Terrell who for her part utilizes the Natural approach, states that it is a must to not interupt students and to correct their mistakes because it won't help. Rardin, on the other hand, said that the teacher should be a language counselor and a language teacher at the same time where the teacher listens to the inner thoughts of the students while guiding them on the language used. 
According to Horwitz et al. (1986), foreign language anxiety affects performance evaluation in terms of social and academic context. They cited three related performance anxieties namely: communication apprehension, test anxiety and fear of negative evaluation. Since communication involves interpersonal communication, communication apprehension is an important concept of foreign language anxiety.

Since student's performance evaluation is a continuous process mostly in a foreign class, another type of anxiety called test- anxiety is relevant to foreign language anxiety. Test- anxiety is defined as a classification of performance anxiety coming from a fear of failure. Most of the students who have this type of anxiety put pressure on themselves by setting a standard that ones they cannot obtain a perfect score; it is already a failure. Another type of anxiety is the fear of negative evaluation. This type of anxiety is an apprehension of other's evaluation, avoidance of any evaluative situation and the anticipation that others would evaluate oneself negatively. Fear of negative evaluation is broader compared to test anxiety since this does not only limit to test- taking but also social situations like interviewing and speaking in a foreign language class. Foreign language anxiety is not only a combination of communication apprehension, text anxiety and fear of negative evaluation in a foreign language learning rather it is a complex of self-perceptions, behaviors, attitudes, beliefs, and feelings arising from the language learning process (Horwitz et al. 1986).

In learning the second language, the focus shifted from teachers to learners which include the affective factors such as motivation, attitude, and anxiety which affects the success of obtaining language learning outcomes. Anxiety, considered to be an important factor in the communicative process, is undeniably a most studied aspect in language learning.

Various studies from different countries were reviewed to assess the trends and gaps in the study.

The study aimed to assess the English Language Anxiety and the Delivery in Oral Communications in relation to the Academic Performance among Grade 8 students at Union National High School in Ubay, Bohol as a basis for proposing intervention measures. It further explored the following sub- problems:

1. What is the profile of the respondents in terms of

\subsection{Age;}

1.2. Sex? 
2. What is the status of Grade 8 students in the aspects of:

2.1. English Language Anxiety;

2.2. Oral Communication Delivery;

2.3. Academic Performance?

3. Is there a significant degree of relationship between the student's profile and the following

3.1. English Language Anxiety;

3.2. Oral Communication Delivery;

3.3. Academic Performance?

4. Is there a significant degree of correlation between the studen 's

4.1. English Language Anxiety and Oral Communication Delivery;

4.2. English Language Anxiety and Academic Performance; and

4.3. Oral Communication Delivery and Academic Performance?

5. What intervention measures could be proposed on the bases of the findings

\section{RESEARCH METHODOLOGY}

The study used the descriptive-normative survey method of research which employed the purposive and complete enumeration sampling technique that only Grade 8 students from all sections were considered as the participants of the study. Furthermore, the research delved into a documentary analysis of the academic performance of Grade 8 students during the Second Grading Periodical Test Results. The tools used in this study were the following: 1) a questionnaire based on a standard tool called, "Foreign Language Classroom Anxiety Scale (FLCAS)" developed by Horwitz, Horwitz and Cope 1986; and 2) a tool based on the Rubric for the Assessment of Oral Communication for Delivery used by Valencia Community College in Orlando Florida. The periodical test administered was a teacher-made test with 40 items subjected to validation by the English coordinator and school principal. Raw scores were used for this study.

The study was conducted at Union National High School in Barangay Union, located seven kilometers from the town proper of the Municipality of Ubay, Bohol. A secondary public high school with a population of 818 students, the school is headed by a Principal I and supported by 30 teachers. 
The participants of the study were 191 Grade 8 students of Union National High School, Ubay, Bohol for the Academic Year 2015-2016. The participants were from all the sections of Grade 8, namely: Courage, Justice, Patience, and Justice. Among 191 participants of Union National High School, 85 students (44.50\%) were at the ages $12-13$ years; 84 students (43.98\%) were at the age of $14-15$ years; 17 students $(8.90 \%)$ were $16-17$ years old; and five students $(2.62 \%)$ were 18 years old and above. There were 81 males $(42.41 \%)$ and 110 females $(57.59 \%)$.

The study used the following statistical treatments: Weighted Mean to gauge the average value of responses to items in the questionnaire, Chisquare to determine the significant degree of relationship between student's profile and English Language Anxiety; Oral Communication Delivery; and Academic Performance. Pearson $r$ was used to determine the correlation between the English Language Anxiety, and Oral Communication Delivery; English Language Anxiety and Academic Performance as well as Oral Communication Delivery and Academic Performance,

\section{RESULTS AND DISCUSSION}

This particular section presents the analysis and interpretation of the data gathered from the responses to the questionnaire, results from the oral delivery rubric and the student's academic performance obtained from their second grading periodical test.

Table 1. English Language Anxiety of the Respondents

$$
\mathrm{N}=191
$$

\begin{tabular}{|c|c|c|c|c|c|c|c|c|c|c|c|}
\hline \multirow{2}{*}{$\begin{array}{l}\text { Behavior, Beliefs, } \\
\text { Feelings, and } \\
\text { Perceptions }\end{array}$} & \multicolumn{2}{|c|}{ SA } & \multicolumn{2}{|c|}{ MA } & \multicolumn{2}{|c|}{ A } & \multicolumn{2}{|c|}{ D } & \multirow[b]{2}{*}{ WM } & \multirow[b]{2}{*}{ DV } & \multirow[b]{2}{*}{$\mathbf{R}$} \\
\hline & $F$ & WV & $F$ & WV & $\mathbf{F}$ & WV & $\mathbf{F}$ & WV & & & \\
\hline $\begin{array}{l}\text { 1. I never feel quite sure } \\
\text { of myself when I am } \\
\text { speaking in my foreign } \\
\text { language class. }\end{array}$ & 27 & 108 & 43 & 129 & 74 & 148 & 47 & 47 & 2.26 & A & 26 \\
\hline $\begin{array}{l}\text { 2. I worry about making } \\
\text { mistakes in foreign } \\
\text { language class. }\end{array}$ & 48 & 192 & 42 & 126 & 78 & 156 & 23 & 23 & 2.60 & MA & 11 \\
\hline $\begin{array}{l}\text { 3. I tremble when I know } \\
\text { that I'm going to be } \\
\text { called on in language } \\
\text { class. }\end{array}$ & 36 & 144 & 56 & 168 & 64 & 128 & 35 & 35 & 2.49 & A & 16 \\
\hline
\end{tabular}




\begin{tabular}{|c|c|c|c|c|c|c|c|c|c|c|c|}
\hline \multirow{2}{*}{$\begin{array}{l}\text { Behavior, Beliefs, } \\
\text { Feelings, and } \\
\text { Perceptions }\end{array}$} & \multicolumn{2}{|c|}{ SA } & \multicolumn{2}{|c|}{ MA } & \multicolumn{2}{|c|}{ A } & \multicolumn{2}{|c|}{ D } & \multirow[b]{2}{*}{ WM } & \multirow[b]{2}{*}{ DV } & \multirow[b]{2}{*}{$\mathbf{R}$} \\
\hline & $\mathbf{F}$ & WV & $F$ & WV & $\mathbf{F}$ & WV & $\mathbf{F}$ & WV & & & \\
\hline $\begin{array}{l}\text { 4. It frightens me when I } \\
\text { don't understand what } \\
\text { the teacher is saying in } \\
\text { the foreign language. }\end{array}$ & 34 & 136 & 55 & 165 & 66 & 132 & 36 & 36 & 2.46 & $A$ & 20 \\
\hline $\begin{array}{l}\text { 5. It bothers me to take } \\
\text { more foreign language } \\
\text { classes. }\end{array}$ & 26 & 104 & 50 & 150 & 51 & 102 & 64 & 64 & 2.20 & A & 27 \\
\hline $\begin{array}{l}\text { 6. During language } \\
\text { class, I find myself } \\
\text { thinking about things } \\
\text { that have nothing to do } \\
\text { with the course. }\end{array}$ & 26 & 104 & 44 & 132 & 56 & 112 & 65 & 65 & 2.16 & $A$ & 29 \\
\hline $\begin{array}{l}\text { 7. I keep thinking that } \\
\text { the other students are } \\
\text { better at languages } \\
\text { than I am. }\end{array}$ & 40 & 160 & 43 & 129 & 83 & 166 & 25 & 25 & 2.51 & MA & 15 \\
\hline $\begin{array}{l}\text { 8. I am usually not at } \\
\text { ease during tests in my } \\
\text { language class. }\end{array}$ & 20 & 80 & 46 & 138 & 49 & 98 & 76 & 76 & 2.05 & A & 30 \\
\hline $\begin{array}{l}\text { 9. I start to panic } \\
\text { when I have to speak } \\
\text { without preparation in } \\
\text { language class. }\end{array}$ & 50 & 200 & 49 & 147 & 69 & 138 & 23 & 23 & 2.66 & MA & 8 \\
\hline $\begin{array}{l}\text { 10. I worry about the } \\
\text { consequences of } \\
\text { failing my foreign } \\
\text { language class. }\end{array}$ & 79 & 316 & 25 & 75 & 71 & 142 & 16 & 16 & 2.87 & MA & 1.5 \\
\hline $\begin{array}{l}\text { 11. I get nervous when } \\
\text { the language teacher } \\
\text { asks questions which } \\
\text { I haven't prepared in } \\
\text { advance. }\end{array}$ & 53 & 212 & 63 & 189 & 62 & 124 & 13 & 13 & 2.82 & MA & 3 \\
\hline $\begin{array}{l}\text { 12. In language class, I } \\
\text { can get so nervous } \\
\text { when I forget things I } \\
\text { know. }\end{array}$ & 53 & 212 & 61 & 183 & 62 & 124 & 15 & 15 & 2.80 & MA & 4 \\
\hline $\begin{array}{l}\text { 13. It embarrasses me to } \\
\text { volunteer answers in } \\
\text { my language class. }\end{array}$ & 51 & 204 & 46 & 138 & 64 & 128 & 30 & 30 & 2.62 & MA & 9 \\
\hline $\begin{array}{l}\text { 14. I would be nervous } \\
\text { speaking in the foreign } \\
\text { language with native } \\
\text { speakers. }\end{array}$ & 77 & 308 & 35 & 105 & 56 & 112 & 23 & 23 & 2.87 & MA & 1.5 \\
\hline $\begin{array}{l}\text { 15. I get upset when } \\
\text { I don't understand } \\
\text { what the teacher is } \\
\text { correcting. }\end{array}$ & 46 & 184 & 50 & 150 & 66 & 132 & 29 & 29 & 2.59 & MA & 12 \\
\hline
\end{tabular}




\begin{tabular}{|c|c|c|c|c|c|c|c|c|c|c|c|}
\hline \multirow{2}{*}{$\begin{array}{l}\text { Behavior, Beliefs, } \\
\text { Feelings, and } \\
\text { Perceptions }\end{array}$} & \multicolumn{2}{|c|}{ SA } & \multicolumn{2}{|c|}{ MA } & \multicolumn{2}{|c|}{ A } & \multicolumn{2}{|c|}{ D } & \multirow[b]{2}{*}{ WM } & \multirow[b]{2}{*}{ DV } & \multirow[b]{2}{*}{$\mathbf{R}$} \\
\hline & $\mathbf{F}$ & WV & $\mathbf{F}$ & WV & $\mathbf{F}$ & WV & $\mathbf{F}$ & WV & & & \\
\hline $\begin{array}{l}\text { 16. Even if I am well } \\
\text { prepared for language } \\
\text { class, I feel anxious } \\
\text { about it. }\end{array}$ & 22 & 88 & 64 & 192 & 76 & 152 & 29 & 29 & 2.41 & A & 22 \\
\hline $\begin{array}{l}\text { 17. I often feel like not } \\
\text { going to my language } \\
\text { class. }\end{array}$ & 13 & 52 & 28 & 84 & 33 & 66 & 117 & 117 & 1.67 & D & \\
\hline $\begin{array}{l}\text { 18. I don't feel confident } \\
\text { when I speak in foreign } \\
\text { language class. }\end{array}$ & 20 & 80 & 54 & 162 & 75 & 150 & 42 & 42 & 2.27 & A & 25 \\
\hline $\begin{array}{l}\text { 19. I am afraid that my } \\
\text { language teacher is } \\
\text { ready to correct every } \\
\text { mistake I make. }\end{array}$ & 24 & 96 & 40 & 120 & 72 & 144 & 55 & 55 & 2.17 & A & 28 \\
\hline $\begin{array}{l}\text { 20. I wouldn't probably } \\
\text { feel comfortable } \\
\text { around native } \\
\text { speakers of the foreign } \\
\text { language. }\end{array}$ & 52 & 208 & 48 & 144 & 61 & 122 & 30 & 30 & 2.64 & MA & 10 \\
\hline $\begin{array}{l}\text { 21. The more I study for } \\
\text { a language test, the } \\
\text { more confused I get. }\end{array}$ & 34 & 136 & 48 & 144 & 53 & 106 & 56 & 56 & 2.31 & A & 23 \\
\hline $\begin{array}{l}\text { 22. I feel pressured to } \\
\text { prepare very well for } \\
\text { language class. }\end{array}$ & 25 & 100 & 59 & 177 & 82 & 164 & 25 & 25 & 2.44 & A & 21 \\
\hline $\begin{array}{l}\text { 23. I always feel that the } \\
\text { other students speak } \\
\text { the language better } \\
\text { than I do. }\end{array}$ & 35 & 140 & 55 & 165 & 66 & 132 & 35 & 35 & 2.47 & A & 18 \\
\hline $\begin{array}{l}\text { 24. I feel very self- } \\
\text { conscious about } \\
\text { speaking the foreign } \\
\text { language in front of } \\
\text { other students. }\end{array}$ & 46 & 184 & 65 & 195 & 60 & 120 & 20 & 20 & 2.72 & MA & 6 \\
\hline $\begin{array}{l}\text { 25. Language class } \\
\text { moves so quickly I } \\
\text { worry about getting left } \\
\text { behind. }\end{array}$ & 52 & 208 & 45 & 135 & 79 & 158 & 15 & 15 & 2.70 & MA & 7 \\
\hline $\begin{array}{l}\text { 26. I feel more tensed } \\
\text { and nervous in my } \\
\text { language class than in } \\
\text { my other classes. }\end{array}$ & 28 & 112 & 65 & 195 & 67 & 134 & 31 & 31 & 2.47 & A & 18 \\
\hline $\begin{array}{l}\text { 27. I get nervous and } \\
\text { confused when I } \\
\text { am speaking in my } \\
\text { language class. }\end{array}$ & 33 & 132 & 52 & 156 & 77 & 154 & 29 & 29 & 2.47 & A & 18 \\
\hline
\end{tabular}




\begin{tabular}{|l|c|c|c|c|c|c|c|c|c|c|c|}
\hline \multirow{2}{*}{$\begin{array}{l}\text { Behavior, Beliefs, } \\
\text { Feelings, and } \\
\text { Perceptions }\end{array}$} & \multicolumn{2}{|c|}{ SA } & \multicolumn{2}{|c|}{ MA } & \multicolumn{2}{|c|}{ A } & \multicolumn{2}{|c|}{ D } & & & \\
\cline { 2 - 13 } & F & WV & F & WV & F & WV & F & WV & WM & DV & R \\
\hline $\begin{array}{l}\text { 28. When I'm on my way } \\
\text { to language class, I } \\
\text { don't feel very sure and } \\
\text { relaxed. }\end{array}$ & 25 & 100 & 56 & 168 & 60 & 120 & 50 & 50 & 2.29 & A & 24 \\
\hline $\begin{array}{l}\text { 29. I feel drained by the } \\
\text { number of rules you } \\
\text { have to learn to speak } \\
\text { a foreign language. }\end{array}$ & 34 & 136 & 69 & 207 & 60 & 120 & 28 & 28 & 2.57 & MA & 13 \\
\hline $\begin{array}{l}\text { 30. I am afraid that the } \\
\text { other students will } \\
\text { laugh at me when } \\
\text { I speak the foreign } \\
\text { language. }\end{array}$ & 52 & 208 & 59 & 177 & 66 & 132 & 14 & 14 & 2.78 & MA & 5 \\
\hline \begin{tabular}{l} 
Composite Mean \\
\hline
\end{tabular}
\end{tabular}

Legend:

$\begin{array}{llll}\text { Mean } & \text { Rating } & \text { Assessment } & \text { Descriptor } \\ 1.00-1.74 & \text { D } & \text { Disagree } & \text { Barely Anxious } \\ 1.75-2.49 & \text { A } & \text { Agree } & \text { Anxious } \\ 2.50-3.24 & \text { MA } & \text { Moderately Agree } & \text { Moderately Anxious } \\ 3.25-4.00 & \text { SA } & \text { Strongly Agree } & \text { Highly Anxious }\end{array}$

The composite mean was 2.48 or "Agree," which means that students were Anxious (A) as they experienced some degree of English language anxiety. These results are supported by the theory of foreign language anxiety where students feel anxious about learning and using the foreign language. These anxieties arise from the uniqueness of the nature of the language learning process.

In the FLCAS questionnaire, statement no.14, which says, "I would be nervous speaking in the foreign language with native speakers" and statement no. 10 "I worry about the consequences of failing my foreign language class," got the highest rating of Moderately Agree with the weighted mean of 2.87. This is a statement of anxious feeling and behavior when faced with social pressures and fear of making mistakes. This finding is also a matter of self-esteem which goes back to Horwitz et al. (1986), who shared that people with low self-esteem would worry what their peers would think; they are pressured with pleasing others. 
On the other hand, statement no. 7, which says, "I keep thinking that the other students are better at languages" had the lowest weighted mean of 2.51 among statements rated as "Moderately Agree." This is about self-concept which affects one's self-esteem. Horwitz et al., (1986) shared that people who have certain levels of self-esteem are less likely to be anxious than are those with low self-esteem.

Moreover, statement no. 3, which says, "I tremble when I know that I'm going to be called on in language class" has been rated with "Agree" with the highest weighted mean of 2.49. This speaks of the learners' anxiety towards the learning environment.

On the other hand, statement no. 8, "I am usually not at ease during tests in my language class" who got the lowest weighted mean of 2.16 among the statements rated as "Agree."

Meanwhile, the only item with the "Disagree" rating is statement no. 17, "I often feel like not going to my language class," with a weighted mean of 1.67. Thus, the students thought that English was not a hindrance for them to attend their classes.

Table 2 shows the oral communication delivery ratings of the participants from the four Grade 8 sections.

Table 2. Oral Communication Delivery

\begin{tabular}{|c|c|c|c|}
\hline \multicolumn{1}{|c|}{ Criteria } & F 191 & \% \\
\hline 1. Eye Contact & & & 1 \\
\hline Beginning & 114 & 59.69 & 2 \\
\hline Developing & 71 & 37.17 & 3 \\
\hline Competent & 6 & 3.14 & 4 \\
\hline Accomplished & 0 & 0.00 & 2 \\
\hline 2. Movement & & & 1 \\
\hline Beginning & 83 & 43.46 & 3 \\
\hline Developing & 85 & 44.50 & 4 \\
\hline Competent & 22 & 11.52 & \\
\hline Accomplished & 1 & 0.52 & 3 \\
\hline 3. Voice & 21 & 10.99 & 1 \\
\hline Beginning & 84 & 43.98 & \\
\hline Developing & & & \\
\hline
\end{tabular}




\begin{tabular}{|c|c|c|c|}
\hline Criteria & F & \% & R \\
\hline Competent & 70 & 36.65 & 2 \\
\hline Accomplished & 16 & 8.38 & 4 \\
\hline 4. Fluency & & & \\
\hline Beginning & 14 & 7.33 & 3 \\
\hline Developing & 38 & 19.90 & 2 \\
\hline Competent & 62 & 32.46 & 1 \\
\hline Accomplished & 77 & 40.31 & \\
\hline
\end{tabular}

As to the rubrics of Oral Communication delivery, Table 2 presents the results that in the criteria for Eye Contact, 59.69 percent got a rating of "Beginning." In terms of Movement, 85 students $(44.50 \%)$ got a rating of "Developing." In the Voice, 84 (43.98\%) had a rating of "Developing," and for the criteria for Fluency, 77 students $(40.31 \%)$ attained a rating of "Accomplished."

Such finding is true to the second language learning theory of Krashen (1987). The results of the oral communication delivery is a continuous growth of the students from elementary to their Grade 8 secondary status. In Krashen's Monitor hypothesis, monitoring through formal education should be reinforced. Affective filter hypothesis also supports the result which stated that those students who have low anxiety and have high confidence and motivation could do better in language acquisition. Thus, the results varied.

Table 3 shows the academic performance of the students during their secodnd periodical test. The academic performance was categorized as follows: 38-40, Excellent; 35-37, Very Good; 33-34, Good; 30-32, Fair; and below 30 as Poor.

Table 3. Academic performance of students

\begin{tabular}{|c|c|c|c|}
\hline Academic Performance & $\mathbf{F}$ & \% & $\mathbf{R}$ \\
\hline $38-40$ & 1 & 0.52 & 4.5 \\
\hline $35-37$ & 1 & 0.52 & 4.5 \\
\hline $33-34$ & 5 & 2.62 & 3 \\
\hline $30-32$ & 7 & 3.66 & 2 \\
\hline below 30 & 177 & 92.67 & 1 \\
\hline Total & 191 & & \\
\hline
\end{tabular}




\section{Legend:}

$\begin{array}{llll}38-40 & \text { Excellent } & 30-32 & \text { Fair } \\ 35-37 & \text { Very Good } & \text { Below 30 } & \text { Poor } \\ 33-34 & \text { Good } & & \end{array}$

Based on the results of the second periodical test of the participants, only one student (0.52\%) attained an Excellent grade, while 177 students $(92.67 \%)$ obtained a Poor grade, which comprised the majority. This goes back to the study of $\mathrm{Li}$ and Pan (2009), which posited that motivation is a factor in the success of second language acquisition. Those students who are highly motivated are most likely to succeed than those who are lowly motivated and often fails in the exam. Based on the results, it seemed that most of the students were lowly motivated.

Table 4 presents the chi-square test between the age and oral communication delivery skills among the participants.

Table 4. Degree of relationship between students' age and oral communication

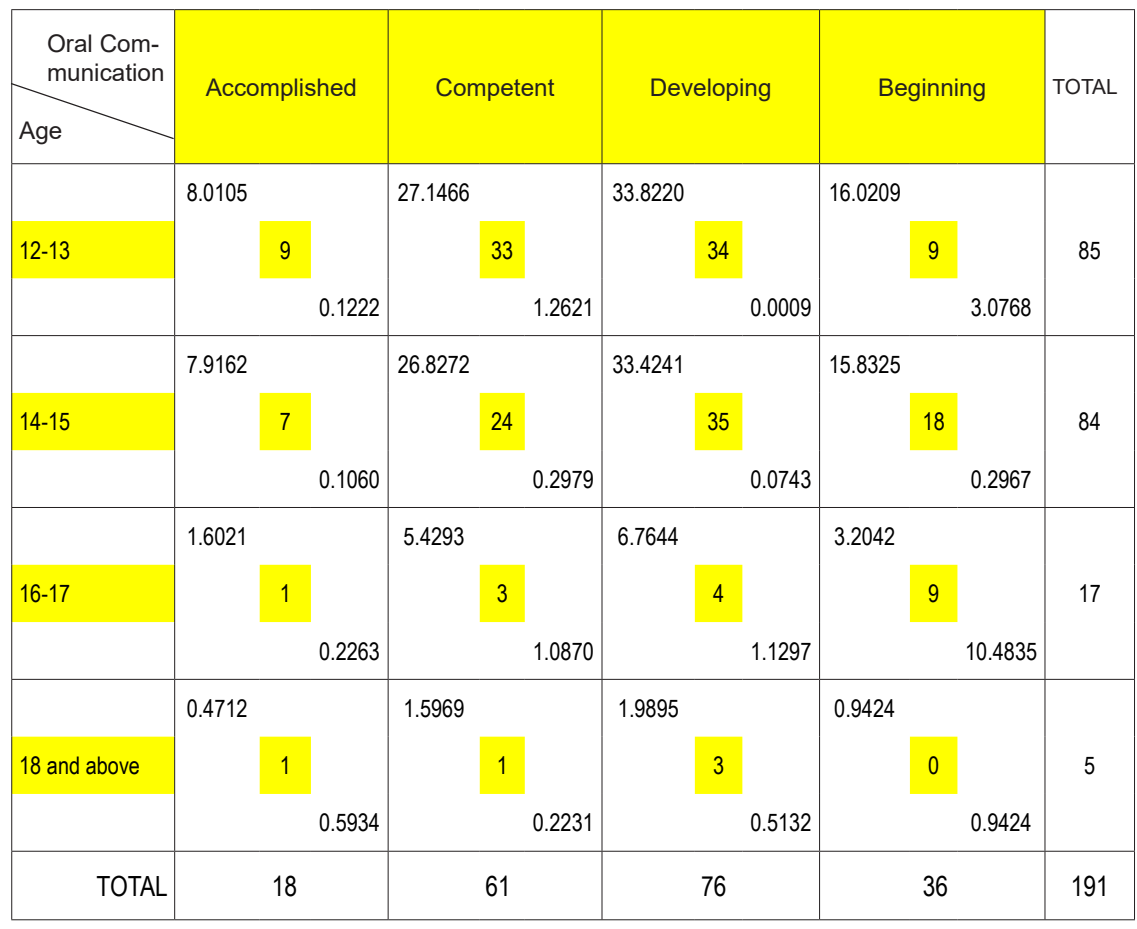


Chi-square $X^{2}=20.4355$

Critical Value of $X^{2}$ at $9 \mathrm{df}$ and 0.05 level of significance is 16.919

Result: Significant

Decision: Reject Null Hypothesis

The obtained Chi-square ratio is 20.4355 which is greater than the critical value of 16.919 at $9 \mathrm{df}$ and 0.05 level of significance, thus, rejecting the null hypothesis. This result showed there was a significant degree of relationship between the age and the students' oral communication. The age significantly affected their oral communication towards the language.

Table 5. Degree of relationship between students' sex and English language anxiety

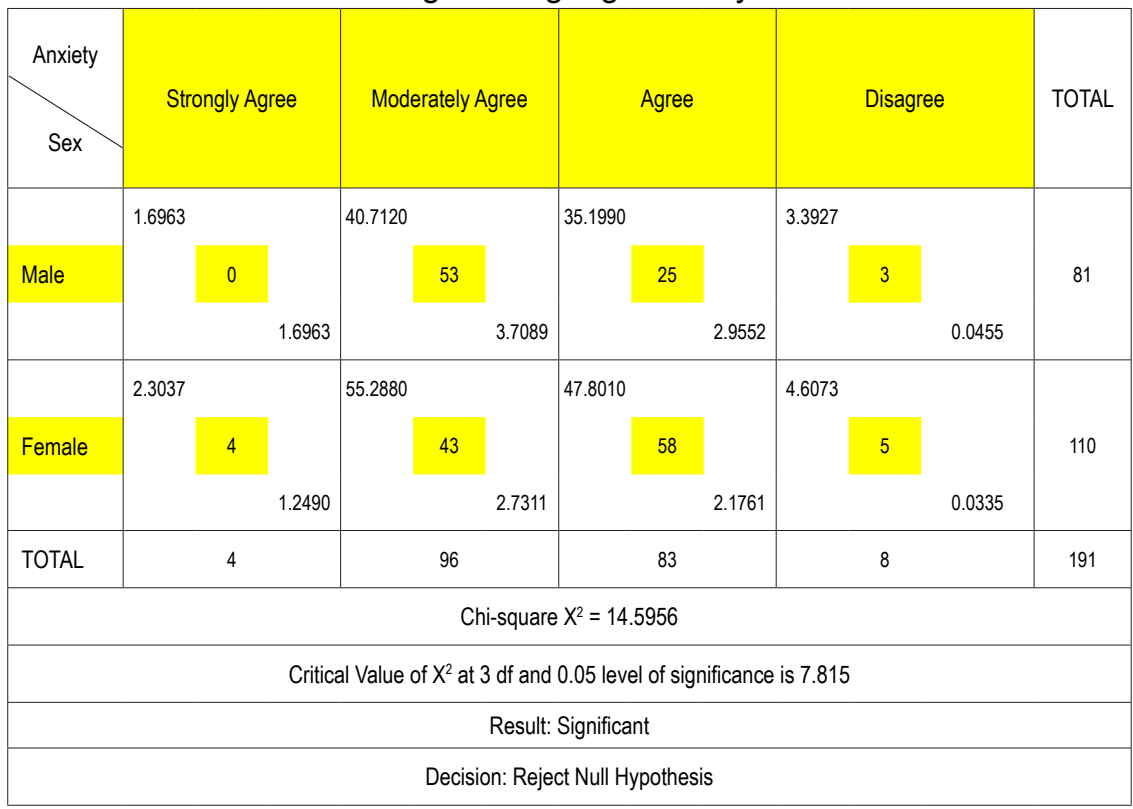

Table 5 presents the Chi-square test between students' sex and their responses to FLCAS. The obtained Chi-square ratio is 14.5956 which is greater than the critical value of 7.815 at $3 \mathrm{df}$ and 0.05 level of significance, thus rejecting the null hypothesis. 
The result showed that there was a significant degree of relationship between sex and the students' English language anxiety. The sex significantly affected their anxiety towards the language.

In this study, the females were more anxious compared to their male counterparts. This result implies that females are more conscious and more worried about dealing with the English language. This situation may be due to different factors such as psychological or emotional and others that may vary with sex. In the study of Horwitz et al., (1986), it is said that foreign language anxiety is not only a combination of communication apprehension, text anxiety and fear of negative evaluation; rather it is a complex mix of self-perceptions, behaviors, attitudes, beliefs, and feelings arising from the language learning process.

Table 6. Degree of relationship between students' sex and oral communication

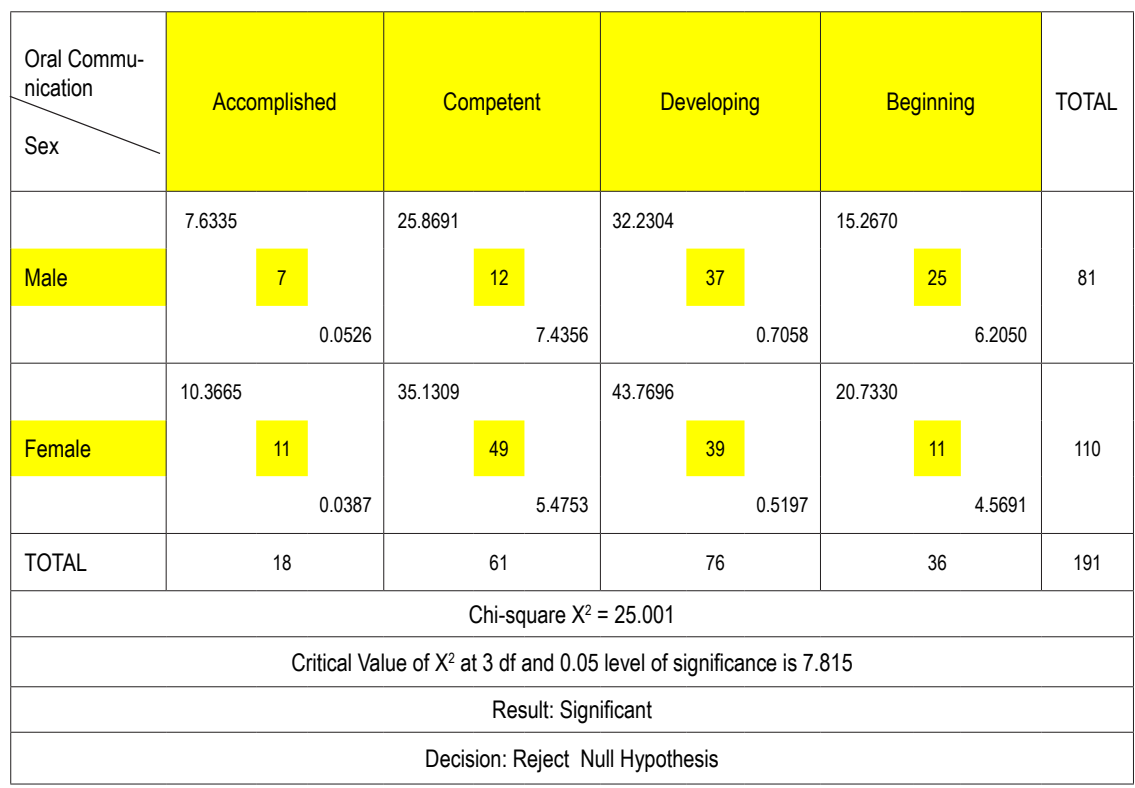

Table 6 presents the Chi-square test between students sex and their oral communication delivery ratings. The obtained Chi-square ratio is 25.001 which is greater than the critical value of 7.815 at $3 \mathrm{df}$ and 0.05 level of significance, thus rejecting the null hypothesis. The result showed that there was a significant degree of relationship between the sex 
and the students' oral communication. The sex significantly affected their oral communication skills towards the language.

Table 7 presents the Chi-square test between students' sex and their academic performance. The obtained Chi-square ratio is 7.9852 which was lesser than the critical value of 9.488 at 4 df and 0.05 level of significance, thus, accepting the null hypothesis.

Table 7. Degree of relationship between students' sex and academic performance

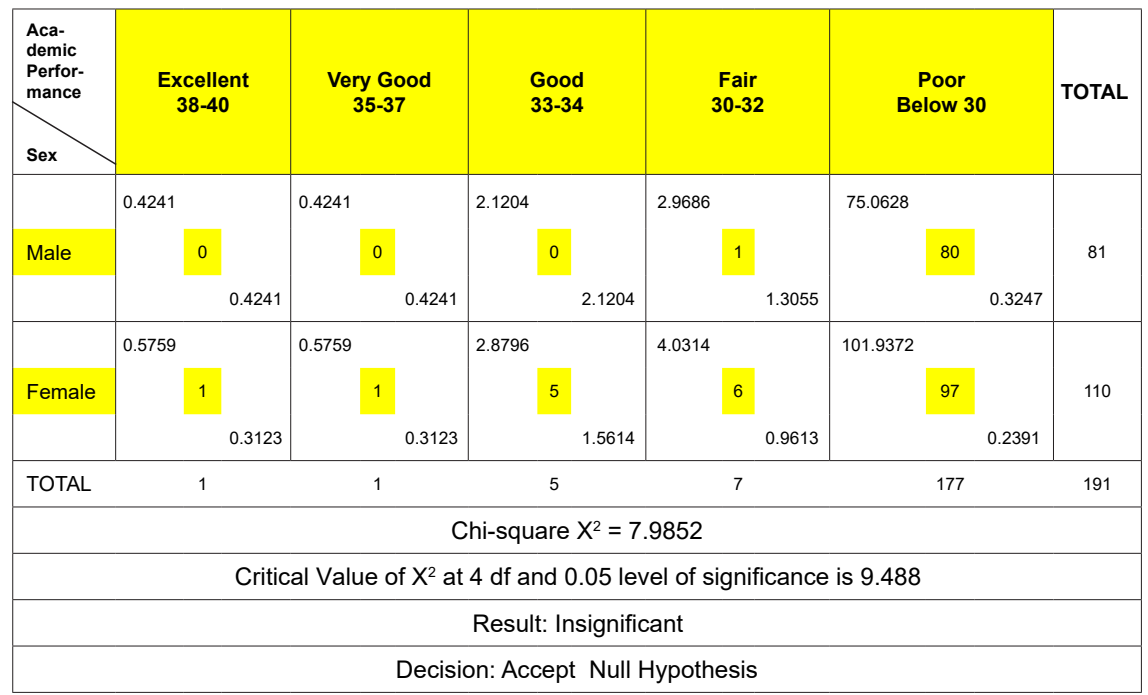

This result showed there was no significant degree of relationship between the sex and the students' academic performance. The sex did not significantly affect their academic performance. This result implies that sex is not a direct factor to the success or failure of students' academic performance.

This finding can be supported by the study conducted by Burgos and Perez (2015), which focused on the attitudes of the learners towards English as a foreign language. The study showed that students positively responded to the need to learn the English language for their future use. This could imply that it is the attitude of learners and not their biological factors that would have a great impact on successful learning and good academic performance. 
To ascertain the degree of correlation between English language anxiety and oral communication delivery of Grade 8 students, the data were subjected to the Pearson product moment correlation formula.

Table 8. Correlation between English language anxiety and oral communication delivery

\begin{tabular}{|l|c|c|c|c|c|}
\hline \multicolumn{1}{|c|}{ Student } & $\begin{array}{c}\text { English } \\
\text { Language } \\
\text { Anxiety } \\
\mathbf{X}\end{array}$ & $\mathbf{X}^{2}$ & $\begin{array}{c}\text { Oral } \\
\text { Communication } \\
\text { Delivery } \\
\mathbf{Y}\end{array}$ & $\mathbf{Y}^{2}$ & $\mathbf{X Y}$ \\
\hline Sum & 473.54 & 1202.82 & 428.74 & 1050.40 & 1058.29 \\
\hline Mean & 2.48 & 2.24 & & \\
\hline$r=(-) 0.09275$ & & \\
\hline Critical Value of $r$ at 189 df and 0.05 level of significance is 0.1946 \\
\hline Result: Insignificant \\
\hline \multicolumn{2}{l}{ Decision: Accept null hypothesis } \\
\hline
\end{tabular}

Table 8 revealed that the obtained correlation coefficient was $(-) 0.09275$ which was lesser than the critical value of 0.1946 at $189 \mathrm{df}$ and 0.05 level of significance, thus accepting the null hypothesis. The result showed that English language anxiety is insignificantly related to their oral communication delivery.

This could be reflected in the Self- Determination theory of Ryan and Deci (2000) wherein intrinsic and extrinsic motivation could affect the performance of the students. If the students are intrinsically motivated, then they could have performed well since they have the interest. While if they are externally motivated, they could just have performed to acquire an external outcome which could be in the form of awards.

Table 9 illustrates the significant degree of correlation between English language anxiety and academic performance of Grade 8 students. 
Table 9. Correlation between English language anxiety and academic performance

\begin{tabular}{|l|c|c|c|c|c|}
\hline Student & $\begin{array}{c}\text { English } \\
\text { Language } \\
\text { Anxiety } \\
\mathbf{X}\end{array}$ & $\mathbf{X}^{2}$ & $\begin{array}{c}\text { Academic } \\
\text { Performance } \\
\mathbf{Y}\end{array}$ & $\mathbf{Y}^{2}$ & $\mathbf{X Y}$ \\
\hline Sum & 473.54 & 1202.82 & 2939.00 & 59223.00 & 7246.42 \\
\hline Mean & 2.48 & & 15.39 & & \\
\hline$r=(-) 0.06324$ & \\
\hline Critical Value of $r$ at $189 \mathrm{df}$ and 0.05 level of significance is 0.1946 & \\
\hline Result: Insignificant \\
\hline
\end{tabular}

The computation produced an $r$ of (-)0.06324 which is lower than the tabular value of r 0.1946 at $189 \mathrm{df}$ and 0.05 level of significance; thus, an insignificant result. The null hypothesis was then accepted. This explains that there was no correlation between English language anxiety and the students' academic performance. The result is somehow contradicted by the study of Park and Lee (2005), wherein there is a negative relation between anxiety and oral performance. This result could be explained to the nature of the students and the environment they are in.

Table 10 portrays the statistical analysis and treatment of the students' oral communication delivery and their academic performance.

Table 10. Correlation between oral communication delivery and academic performance

\begin{tabular}{|l|c|c|c|c|c|}
\hline Student & $\begin{array}{c}\text { Oral } \\
\text { Communica- } \\
\text { tion } \\
\text { Delivery } \\
\mathbf{X}\end{array}$ & $\mathbf{X}^{2}$ & $\begin{array}{c}\text { Academic } \\
\text { Performance } \\
\mathbf{Y}\end{array}$ & $\mathbf{Y}^{2}$ & $\mathbf{X Y}$ \\
\hline Sum & 428.74 & 1050.40 & 2939.00 & 59223.00 & 7143.14 \\
\hline Mean & 2.24 & & 15.39 & \\
\hline$r=0.491848$ & & & \\
\hline Critical Value of $r$ at 189 df and 0.05 level of significance is 0.1946 & \\
\hline Result: Significant \\
\hline \multicolumn{5}{l}{ Decision: Reject null hypothesis } \\
\hline
\end{tabular}


Further testing the significant correlation using $\mathrm{t}$-test, $\mathrm{t}=7.766104$

Critical Value of $t$ at $189 \mathrm{df}$ and 0.05 level of significance is 1.96

Result: Significant

Decision: Reject null hypothesis

The computation yielded an $r$ value of 0.491848 referred to the critical value of $r$ at $189 \mathrm{df}$, and 0.05 level of significance is 0.1946 was found to be higher: hence the result is significant. The null hypothesis was rejected.

The significant was further tested using t-test. The obtained t-value was 7.766104 which was greater than the critical value of $r$ at $189 \mathrm{df}$ and 0.05 level of significance of 1.96 . The result showed that it is significant, rejecting the null hypothesis.

This is true to the theory of ZPD by Vygotsky (1978) wherein a child can best learn the second language through collaborative work and guided practice with a skillful peer. This could be maximized during classroom activities like theater play, speech choir and role plays. Collaboration and group work can help maximize the child's potential to learn a second language.

\section{CONCLUSION}

Based from the findings, the following conclusions are deemed warranted:

1. The students all agreed that they experienced English Language Anxiety as manifested by the composite mean of 2.48 rated as Agree or assessed that students are Anxious. There were 14 items rated as Moderately Agree, 15 items as Agree and one item rated as Disagree.

2. In terms of the student's oral communication delivery ratings, most of the students had Beginning rate on their eye contact, Developing rating on both movement and voice; and a rating of Accomplished on Fluency.

3. In the student's academic performance, most of the students were considered as having poor grades having failed in the second periodical test.

4. In terms of the degree of relationship, the age of the students did not significantly affect their anxiety towards the language and their 
academic performance. This finding implied that no matter what age, the English language anxiety and academic performance of the students are not affected. However, their age significantly affect their oral communication towards the language. In this study, ages 12-13 were better performing compared to those who 14 and above.

5. In the degree of relationship in terms of sex, the data showed that sex significantly affected the students anxiety level and their oral communication. In this study, the females were more anxious than males but they were better speakers than the males. However, sex did not significantly affect the students' academic performance. This implied that sex is not a factor that affects the academic performance of a student.

6. In terms of the Degree of Correlation, the data showed that there is no significant relationship between English language anxiety and their oral communication delivery as well as English language anxiety and the student's academic performance, thus accepting the null hypotheses. However, the oral communication delivery and the academic performance of the students had significant degree of correlation as the computation yielded an $r$ value of 0.491848 referred to the critical value of $r$ at $189 \mathrm{df}$ and 0.05 level of significance is 0.1946 was found to be higher and has been further tested using t0test. The obtained value was 7.766104 which was greater than the critical value of $r$ at $189 \mathrm{df}$ and 0.05 level of significance of 1.96 . The result showed that it is significant, rejecting the null hypothesis.

\section{RECOMMENDATIONS}

From the given findings and subsequent conclusions, the following recommendations are provided:

1. To Raise Confidence Level. A highly motivating atmosphere of imposed "English Only Please" policy should be implemented to encourage students to practice the use of the English language in social encounters. Awards and incentives may be given to diligent and participative students. All school teachers should be articulate and learned enough in using the English language to model what students are expected to be. 
2. New Teaching Strategies. Teachers should innovate strategies that will not only measure one macro-skill rather, activities that will solicit the need to exercise the listening, reading, writing and speaking skills.

3. Implementing Co-curricular Activities. Students should be strongly encouraged to participate in activities that will allow them to do things by themselves and showcase their own prowess. In that way, it does not only allow them to exercise what they can but rather exercise their confidence as well. There should be integration between English curriculum and extra-curricular activities to motivate students to be better in their academics to use it for further competitions. Extracurricular activities should be a vehicle for the enhancement and development of students' skills

4. Upgrade of School Facilities and Amenities. The administration should provide audio-visual facilities and highly conducive rooms that will improve the teaching-learning process. In that way, the teachers can effectively deliver and the students can raise the level of comprehension.

5. Parents Involvement and Community Partnership. The school should find ways to reach out to parents through school community ventures - to help assist in helping their children learn better and establish confidence by incorporating English to their everyday lives.

6. Annual Diagnostic Tests. The administration should institutionalize diagnostic tests in English communication skills. This is administered at the start of the school year to find out the needs of students; this recommendation would aid teachers in addressing such needs. A year-end diagnostic test is administered to measure development among students.

7. Implementation of Intervention Measures. The implementation of the proposed intervention measures are earnestly desired by the researchers.

\section{REFERENCES CITED}

Burden, P. (2004). The teacher as facilitator: Reducing anxiety in the EFL university classroom. JALT Hokkaido Journal, 8(1), 3-18. Retrieved from https://goo.gl/NLmx1d, (accessed last 15 December 2015).

Burgos, E. G., \& Pérez, S. P. (2015). Chilean 12th graders' Attitudes towards English as a Foreign Language. Colombian Applied Linguistics 
Journal, 17(2), 313-324. Retrieved from https://goo.gl/NmsWV3, (accessed last 14 December 2015).

Horwitz, E. K., Horwitz, M. B., \& Cope, J. (1986). Foreign language classroom anxiety. The Modern language journal, 70(2), 125-132. Retrieved from https://goo.gl/djT8jM, (accessed last 14 December 2015).

Kirkpatrick, A. (2008). English as the official working language of the Association of Southeast Asian Nations (ASEAN): Features and strategies.English Today, 24(02), 27-34. Retrieved from https://goo.gl/ jGgPF5, (accessed last 15 December 2015).

Krashen, S. D. (1987). Principles and practice in second language acquisition. New York. Retrieved from https://goo.gl/CCdH6x, (accessed last 14 December 2015).

Li, P., \& Pan, G. (2009). The Relationship between motivation and achievement-A survey of the study motivation of English majors in Qingdao Agricultural University. English Language Teaching, 2(1), 123. Retrieved from https://goo.gl/ksfWqJ, (accessed last 14 December 2015).

Maclntyre, P. D., \& Gardner, R. C. (1991). Methods and Results in the Study of Anxiety and Language Learning: A Review of the Literature*. Language learning, 41(1), 85-117. Retrieved from https:// goo.gl/DcrHmx, (accessed last 14 December 2015).

Park, H., \& Lee, A. R. (2005). L2 learners' anxiety, self-confidence and oral performance. In 10th Conference of Pan-Pacific Association of Applied Linguistics, Edinburgh University, conference proceedings (pp. 197208). Retrieved from 14 December 2015).

Rubrics for Oral and Written Communication. (2006). Retrieved from https:// goo.gl/UmRzMk, (accessed last 14 December 2015).

Ryan, R. M., \& Deci, E. L. (2000). Self-determination theory and the facilitation of intrinsic motivation, social development, and wellbeing. American psychologist, 55(1), 68. Retrieved from https://goo.gl/ 
ucpZqC, (accessed last 15 December 2015).

Vygotsky, L. S. (1978). Mind in society: The development of higher psychological processes. Cambridge, MA: Harvard University Press. Retrieved from https://goo.gl/NT7xGe, (accessed last 14 December 2015).

Young, D. J. (1991). Creating a Low Anxiety Classroom Environment: What Does Language Anxiety Research Suggest?. The modern language journal, 75(4), 426-437. Retrieved from https://goo.gl/pgsdWR, (accessed last 14 December 2015).

Young, D. J. (1992). Language anxiety from the foreign language specialist's perspective: Interviews with Krashen, Omaggio Hadley, Terrell, and Rardin.Foreign Language Annals, 25(2), 157-17. Retrieved from https://goo.gl/ABRL8F, (accessed last December 2015). 